\title{
Internalisasi Nilai-Nilai Gender Melalui Aktivitas Literasi Dalam Keluarga Pegiat Literasi Makassar
}

\author{
Harnita Rahman', M. Tamar', M.E. Fachry ${ }^{3}$ \\ ${ }^{123}$ Universitas Hasanuddin Makassar \\ Email: nitaibumaha@gmail.com
}

\begin{tabular}{llll}
\hline Submitted & $:$ October, 22 $2^{\text {th }}, 2020$ & Revision & $:$ May, $31^{\text {th }}, 2021$ \\
Reviewed & $:$ January, $2^{\text {nd }}, 2021$ & Published & $:$ June, $18^{\text {th }}, 2021$ \\
\hline
\end{tabular}

\begin{abstract}
This study aims to identify gender values through literacy activities and analyze their effects on gender relations in literacy activist families in Makassar. This research is a qualitative research using descriptive analysis. Data obtained through literature review, interview and observation. The informants were selected by purposive sampling by determining 2 families of literacy activists, namely Paradigma Institute and Kampung Buku in Makassar City, South Sulawesi. The data were processed using coding techniques and analyzed using family ecology theory and socialist feminist theory. The results showed that literacy activities in the form of the establishment of libraries and initiation of learning spaces carried out by literacy activists in their homes, contained gender values namely openness, equality, and cooperation. Internalization of gender values through literacy activities affects the gender relations between husband, wife and children in the family. This form of internalization of values is reflected in the decision making process in determining education and childcare as well as in the division of labor in the household.
\end{abstract}

Keywords: family; family ecology; feminist socialism; literacy activities; gender values

Abstrak: Penelitian ini bertujuan mengidentifikasi nilai-nilai gender melalui aktivitas literasi dan menganalisis pengaruhnya terhadap relasi gender dalam keluarga pegiat literasi di Makassar. Penelitian ini merupakan penelitian kualitatif yang menggunakan analisis deskriptif. Data diperoleh melalui kajian pustaka, wawancara dan observasi. Informan dipilih secara purpose sampling dengan menetapkan 2 keluarga pegiat literasi yaitu Paradigma Institute dan Kampung Buku di Kota Makassar, Sulawesi Selatan. Data diolah menggunakan teknik koding dan dianalisis dengan menggunakan teori ekologi keluarga dan teori feminis sosialis. Hasil penelitian memperlihatkan 
bahwa aktivitas literasi berupa pendirian perpustakaan dan inisiasi ruang belajar yang dilakukan oleh pegiat literasi di rumah mereka, mengandung nilai-nilai gender yaitu nilai keterbukaan, kesetaraan, dan kerja sama. Internalisasi nilai nilai gender melalui kegiatan literasi berpengaruh pada relasi gender antara suami, istri dan anak di dalam keluarga. Bentuk internalisasi nilai ini tergambar pada proses pengambilan keputusan dalam menenentukan pendidikan dan pengasuhan anak serta dalam pembagian kerja dalam rumah tangga.

Kata Kunci: aktivitas literasi; ekologi keluarga; feminis sosialis; keluarga; nilai-nilai gender

\section{Pendahuluan}

Indonesia, dalam kurun waktu 10 tahun terakhir telah menunjukkan angka penurunan atas ketimpangan gender dalam skena pembangunan ekonomi global (Women, Business and the Law, 2019). Walau begitu, tantangan pembangunan berperspektif gender menurut Mansour Faqih (Mansour, 2016) justru sedang menuju tahapan tantangan baru yaitu pembangunan berperspektif gender yang secara integral diharapkan menjadi pola hidup keseharian. Hal ini tidak hanya akan mendorong terciptanya kebijakan manajemen dan keorganisasian yang berasaskan kesetaraan dan keadilan gender, namun akan menciptakan individu lalu kelompok masyarakat yang berperspektif gender.

Untuk menjawab tantangan ini, diperlukan keterlibatan kelompok sosial terkecil dalam tatanan masyarakat yaitu keluarga. Keluarga sebagai sebuah organisasi sosial perlu melibatkan diri dalam transformasi sosial. Berdasarkan penelitian terkait teknik analisis gender dalam keluarga, Herien menemukan bahwa penguatan persepektif gender di tingkat keluarga akan berdampak pada keadaan adil gender seperti dalam bidang pendidikan, kesehatan dan tenaga kerja serta ekonomi, trafficking dan domestic violence bisa teratasi, pola pengasuhan akan mengacu pada pengasuhan yang berperspektif gender, kualitas anak akan meningkat dan diikuti oleh meningkatnya kesejahteraan keluarga baik fisik, sosial, ekonomi, mental/ psikologi maupun spiritual. (Herien, 2015)

Sayangnya, keluarga justru menjadi salah satu kelompok yang paling rentan terhadap tindak kekerasan baik verbal maupun psikis. Streotipe, marjinalisasi, subordinasi, pelecehan seksual, beban ganda, hingga kekerasan banyak terjadi di lingkungan keluarga terdekat (Lilis, 2015) Hal ini juga disajikan dalam laporan Komnas Perempuan tahun 2019 yang menunjukkan bahwa dari 2.341 kasus 
kekerasan terhadap anak peremuan, terdapat 770 kasus yang merupakan hubungan inses yaitu dari orang terdekat mereka dalam keluarga. (Komnas Perempuan, 2020)

Pendidikan keluarga menjadi salah satu variable penting dalam pembangunan manusia. Hal tersebut semakin terbukti saat Kementrian Pendidikan dan Kebudayaan di tahun 2015 mencanangkan program pendidikan keluarga dengan membentuk Direktorat Pembinaan Pendidikan Keluarga berdasarkan persetujuan Kementerian Pendayaagunaan Aparatur Negara dan Reformasi Birokrasi yang kemudian ditetapkan melalui Peraturan Menteri Pendidikan dan Kebudayaan nomor 11 tahun 2015 tentang Organisasi dan Tata Kerja Kementerian Pendidikan dan Kebudayaan yang merancang agar pendidikan keluarga dijalankan bersinergi dengan sistem pendidikan nasional. Salah satu program yang dicetuskan adalah Gerakan Literasi Nasional.

Gerakan Literasi Nasional meliputi aktivitas yang diinisiasi individu atau kelompok untuk memajukan etos belajar dengan cakupan yang lebih luas, bukan hanya baca tulis semata. Praktik-praktik baik Gerakan Literasi telah berkembang di Makassar. sejak 2012. Gerakan Literasi Makassar melalui kegiatan literasi dalam skala internasional maupun nasional mulai memperlihatkan geliatnya. Perkembangan tersebut juga didukung dengan hadirnya komunitas-komunitas literasi baik yang digagas oleh lembaga, kelompok, maupun individu. Hal yang tidak kalah uniknya, beberapa pegiat literasi di Makassar tidak berhenti setelah mereka berkeluarga dan justru melibatkan keluarganya dalam aktivitas literasi yang lebih besar.

Fenemona ini menggiring peneliti pada pertanyaan terkait aktivitas literasi dan nilai gender dalam keluarga. Dalam penelitian Lilis Widaningsih berjudul Relasi Gender dalam Keluarga : Internalisasi Nilai-Nilai Kesetaraan dalam memperkuat Fungsi Keluarga, menemukan bahwa dengan menginternalisasi nilainilai gender dalam keluarga akan membangun relasi antar anggota keluarga dengan seimbang. Dalam penelitian ini belum dikemukakan aktivitas apa saja yang bisa menginternalisasi nilai gender dalam keluarga.

Temuan penelitian tersebut saya kembangkan dengan menambah variable aktivitas literasi yang dilakukan oleh keluarga aktivis literasi di Makassar dan relasi yang mereka bangun dalam keluarga. Penelitian ini akan mengidentifikasi nilainilai gender melalui aktivitas literasi yang dilakukan di rumah pegiat literasi di Makassar menggunakan teori ekologi keluarga yang menjelaskan bahwa habitus keluarga terbentuk dari konsistensi lingkungan dalam melakukan aktivitas yang sama dan berulang dalam jangka waktu yang lama. 
Penelitian ini juga menganalisis pengaruh nilai-nilai gender tersebut terhadap relasi gender dalam keluarga, khususnya untuk proses pengambilan keputusan dalam penentuan pendidikan dan pengasuhan anak serta penentuan pembagian kerja dalam rumah tangga berdasarkan teori feminism sosialis.

\section{Metode Penelitian}

Penelitian ini adalah penelitian kualitatif dengan metode deskriptif. Penelitian ini dilakukan di Kota Makassar, Sulawesi Selatan, selama 4 bulan, sejak Februari hingga Juli 2020. Populasi dalam penelitian ini adalah keluarga pegiat literasi di kota Makassar sebanyak sebelas keluarga. Sampel penelitian ditetapkan 2 keluarga pegiat secara purposive berdasarkan kategori tempat pelaksanaan kegiatan dan anggota keluarga. Secara spesifik peneliti memilih keluarga pegiat literasi yang telah memiliki anak dan melakukan aktivitas literasi di rumah mereka yaitu Kampung Buku dan Paradigma Institute.

Penelitian ini menggunakan beberapa teknik pengumpulan data yaitu wawancara, observasi dan studi literature. Wawancara dilakukan dengan metode wawancara tidak terstruktur, dengan mewawancarai pegiat, istri, anak,dan dua orang pustakawan yang telah beraktivitas di komunitas tersebut selama dua tahun terakhir. Metode observasi dilakukan secara langsung dan juga dibantu oleh pustakawan yang tersebut di atas.

Penelitian ini menggunakan tekhnik analisis koding untuk mendapatkan gambaran fakta sebagai satu kesatuan analisis data kualitatif dan teknik mengumpulkan serta menarik kesimpulan analisis psikologis terhadap data yang diperoleh. (Mahpur : 2018) Selanjutnya akan disajikan dalam bentuk tabel dengan mengklasifikasi hasil koding sesuai dengan hasil wawancara yang berdasarkan pada permasalahan penelitian.

\section{Hasil Dan Pembahasan}

Kampung Buku

Kampung Buku adalah salah satu komunitas literasi di Makassar, yang berkembang dan dikenal sebagai salah satu perpustakaan komunitas yang pada awalnya dikelola langsung oleh Penerbit Ininnawa sejak tahun 2008 yang saat itu berada di kawasan Tamalanrea, Makassar. Sejak berpindah ke daerah Panakukang 
beralamat di kompleks CV Dewi Jln Abd. Dg Sirua 192 E, tempat ini secara langsung dikelola oleh AR,45th. AR beserta istri FT,39th menjadikan rumah pribadi mereka menjadi sekretariat komunitas Kampung Buku. dan sekaligus menggawangi Kampung Buku bersama teman-teman relawan lainnya yang biasa disebut "warga" Kampung Buku.

Hampir lebih dari satu dekade, Kampung Buku menjadi salah satu alternative ruang belajar bagi anak-anak muda di Makassar yang sejak awal berfokus pada kegiatan-kegiatan penulisan, penelitian, dan penerbitan dengan mengedapankan program-program yang bersifat volunterisme. Sebagaimana konsep perpustakaan, pengunjung Kampung Buku dapat membaca di tempat, atau dapat meminjamnya selama beberapa hari dengan ketentuan yang berlaku. yaitu dengan menyetor uang pendaftaran sebesar Rp50.000,00 disertai fotocopy KTP atau kartu pengenal lain semisal kartu mahasiswa atau SIM

Bersama Penerbit Ininnwawa, Kampung Buku telah menerbitkan beberapa judul buku, antara lain: Assikalaibineng: Kitab Persetubuhan Bugis, Perkawinan Bugis: Refleksi Status Sosial dan Budaya di Baliknya, Diaspora Bugis, Kuasa Berkat dari Belantara dan Langit: Struktur Transformasi Agama Orang Toraja di Mamasa, Sulawesi Barat, Kekuasaan Raja, Syeikh, dan Ambtenaar: Kekuasaan Tradisional dan Pengetahuan Simbolik Makassar, Makassar Nol KM, Jurnalisme Plat Kuning, Ekspedisi Pelayaran Akademis, Halaman Rumah/Yard, dan Kota Diperam dalam Lontang.

Sebagai komunitas literasi, dalam menjalankan aktivitasnya Kampung Buku menggunakan ruang tamu dan teras rumahnya sebagai perpustakaan, kantor sekaligus tempat beraktivitas. Hingga kini fasilitas yang ada di Kampung Buku, baik buku maupun alat penunjang aktivitas terus bertambah.

Berikut adalah fasilitas yang dimiliki Kampung Buku

Tabel 1. Fasilitas Perpustakaan di Kampung Buku

\begin{tabular}{clll}
\hline No & Jenis Fasilitas & Jumlah & Keterangan \\
\hline 1 & Rak Buku Besar & 4 buah & 380 buku/rak \\
2 & Rak Buku Kecil & 8 buah & 125 buku/rak \\
3 & Meja & 4 buah & - \\
\hline
\end{tabular}




\begin{tabular}{clll}
\hline No & Jenis Fasilitas & Jumlah & Keterangan \\
\hline 4 & Kursi & 22 buah & - \\
5 & Komputer & 2 buah & - \\
\hline
\end{tabular}

Sumber; Data Observasi 2020

Jumlah koleksi buku di Kampung Buku hingga tahun 2020 tercatat lebih dari 2.520 buah. Dengan berbagai genre buku yang beragam, mulai seri cerita komik, chicklit \& teenlit, majalah khusus wanita seperti Elle atau Kartini, majalah musik Rolling Stone, seri penelitian populer National Geographic, novel, buku sejarah dan buku sosial lainnya.

Perpustakaan Kampung Buku terbuka dari hari Senin- Minggu, Pukul 10.00 sampai 21.00 WITA. Pengunjung yang datang prosentasenya lebih besar saat akhir pekan di hari Sabtu dan Minggu atau saat ada kegiatan yang diinisiasi oleh pustakawan seperti diskusi buku, nonton film dan kelas merajut. Pengunjungnya juga dari berbagai macam kelompok masyarakat. Ada siswa SMA, mahasiswa dari berbagai kampus, dan masyarakat umum.

Kampung Buku juga bersama Tanah Indie menginisiasi beberapa program baik berskala lokal, nasional, maupun internasional. Berikut daftar program Kampung Buku ditampilkan dalam tabel berikut

Tabel 2. Program Kampung Buku

\begin{tabular}{|c|c|c|c|}
\hline No & Jenis Kegiatan & Pelaksanaan & Peserta \\
\hline 1 & Bom Benang & Benteng Retterdam, 2013 & $\begin{array}{l}32 \text { orang } \\
(26 \mathrm{P}, 6 \mathrm{~L})\end{array}$ \\
\hline 2 & $\begin{array}{l}\text { Bom Benang "Yarn } \\
\text { on Yard" }\end{array}$ & Kampung Buku, 2015 & 87 orang \\
\hline 3 & Benang Kandung & $\begin{array}{l}\text { Jalan Barukang III, Jalan } \\
\text { Barukang IV, Kawasan Batua } \\
\text { Manggala, kawasan Mariso, dan } \\
\text { Jalan Sukaria. } 2016\end{array}$ & 456 orang \\
\hline 4 & Benang dan Sungai & Sungai Sinrejala, 2017 & 229 orang \\
\hline 5 & Makassar Biennale 1 & $\begin{array}{l}\text { GTC dan Gedung Kesenian, } \\
2015\end{array}$ & 300 orang \\
\hline
\end{tabular}




\begin{tabular}{clll}
\hline No & Jenis Kegiatan & Pelaksanaan & Peserta \\
\hline 6 & Makassar Biennale 2 & UNM, 2017 & 500 orang \\
7 & Makassar Biennale 3 & $\begin{array}{l}\text { Makassar, Bulukumba, Pare- } \\
\text { pare, dan Sulbar 2019 }\end{array}$ & 1200 orang \\
& & & \\
\hline
\end{tabular}

Sumber; Data Observasi 2020

Dalam pelaksanaan program, Kampung Buku mengajak keterlibatan sebanyak mungkin mahasiswa dan masyarakat umum untuk terlibat. Baik perempuan maupun laki-laki dengan semangat kesukarelawanan.

Sementara, untuk menjalankan perpustakaan dan program mingguan, Kampung Buku dibantu oleh pustakawan sebanyak 5 orang, 3 perempuan dan dua laki-laki. Dua diantaranya, 1 laki-laki dan 1 perempuan (RF.25th, dan WS.21th) juga menjadi informan dalam penelitian ini.

Untuk program yang lebih besar, Kampung Buku sering menginisiasi program yang sifatnya kolaboratif bersama komunitas literasi, atau komunitas seni baik ditingkatan lokal, nasional, maupun internasional. Berikut program kerja sama Kampung Buku

Tabel 3. Kerjasama Program Kampung Buku

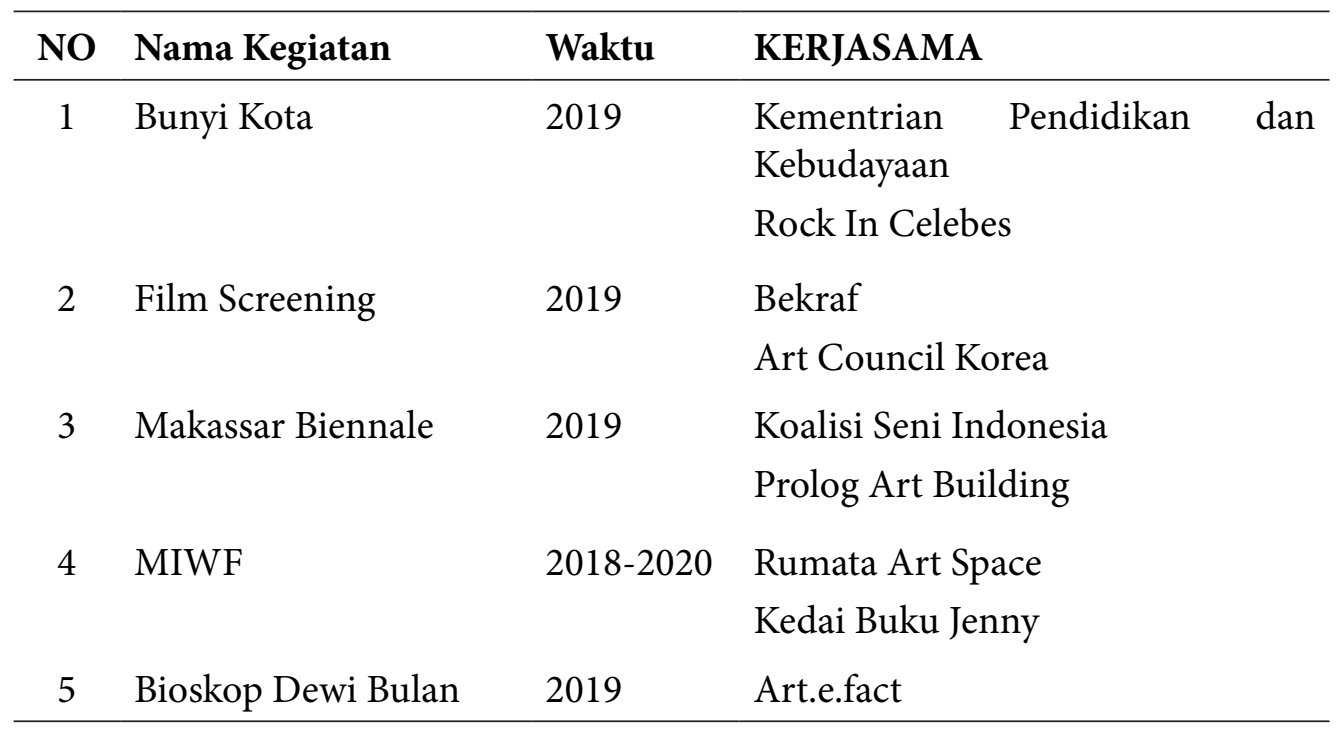

Sumberinstagram @kampungbuku 


\section{Paradigma Institute}

Paradigma Institute secara resmi diinisiasi sejak 1993 oleh Sulhan Yusuf, awalnya bernama Yayasan Pendidikan Pengembangan dan Penelitian Paradigma di kediamannya di Jalan Alauddin. Paradigma Institute didirikan berdasarkan keinginan besar Sulhan untuk membuka ruang belajar, ruang diskusi dan kajian bersama teman-temannya, dan memilih rumahya sendiri sebagai tempat beraktivitas.

Perpustakaan Paradigma Institute berada di ruang tamu rumah Keluarga SY (55). Terbuka dari hari Senin- Minggu pukul 09.00 sampai pukul 20.00 WITA. Untuk menjalankan fungsi sebagai perpustakaan, Paradigma Institute hingga hari ini memiliki beberapa fasilitas yang bisa digunakan oleh pengunjung.

Berikut fasilitas yang dimiliki Paradigma Institute

Tabel 4. Jenis Fasilitas Perpustakaan Paradigma Institute

\begin{tabular}{clll}
\hline No & Jenis Fasilitas & Jumlah & Keterangan \\
\hline 1 & Rak Buku Besar & 4 buah & 220 buku per rak \\
2 & Rak Buku Kecil & 2 buah & 80 buku per rak \\
3 & Meja besar & 1 buah & \\
4 & Meja Kecil & 2 buah & \\
5 & Kursi & 12 buah & \\
\hline
\end{tabular}

Sumber; Data Observasi 2020

Tercatat hingga tahun 2020, koleksi buku di perpustakaan Paradigma Institute mencapai angka 1040 judul, namun sayangnya belum pernah dikategorisasikan menurut jenrenya. Buku-buku tentang ilmu sosial dan parenting adalah kategori yang mendominasi judul buku yang tersedia di perpustakaan Paradigma Institute.

Perpustakaan yang menjadi basis komunitas lalu melahirkan inisiatif program belajar yang berkelindan dengan aktivitas literasi lainnya yang diikuti oleh berbagai peserta. Kebanyakan adalah mahasiswa dan masyarakat umum.

Berikut data program dan peserta dari kelas-kelas yang dilaksanakan di Paradigma Institute. 
Tabel 5. Program Paradigma Institute

\begin{tabular}{clll}
\hline No & Nama Kegiatan & Pelaksanaan & Peserta \\
\hline 1 & Kelas Menulis & Paradigma Institute, 2015 & 20 orang $(12 \mathrm{~L}, 8 \mathrm{P})$ \\
2 & Kelas Parenting & Paradigma Institute, 2016 & 15 orang $(10 \mathrm{~L}, 5 \mathrm{P})$ \\
3 & Kelas Menulis & Paradigma Institute, 2018 & 10 orang $(7 \mathrm{~L}, 3 \mathrm{P})$ \\
4 & Kelas Parenting & Paradigma Institute, 2017 & 11 orang $(1 \mathrm{~L}, 10 \mathrm{P})$ \\
\hline
\end{tabular}

Sumber; Data Observasi 2020

Program ini ada yang berjalan sekali sepekan, ada yang berjalan dua kali dalam sepakan yang bisa diikuti secara gratis. Untuk kelas Matematika dan kelas Bahasa Inggris dikenakan bayaran dengan harga yang terjangkau. Untuk menjalankan program sekaligus perpustakaan, SY dibantu oleh beberapa relawan. peneliti memilih dua diantaranya untuk menjadi informan. Laki-laki berusia 26 tahun (BS) dan perempuan berusia 35 tahun (MN) dan juga SY(53), istrinya MM 48th, dan anaknya NAM, 24 th.

Selain program yang dilakukan rutin, Paradigma juga berkolaborasi dengan beberapa komunitas untuk menjalankan program bersama baik dilakukan di rumah maupun dilakukan di luar. Berikut program kolaborasi yag tercatat melalui media sosial mereka.

Tabel 6. Kerjasama Program Paradigma Institute

\begin{tabular}{clll}
\hline NO & Kegiatan & Waktu & Kerja sama \\
\hline 1 & $\begin{array}{l}\text { Kelas Literasi Angk. } \\
\text { Paradigma Institute }\end{array}$ & 2017 & Smart Coffe \\
& Kala Literasi \\
2 & Tutur Jiwa & 2017 & Dialektika \\
3 & Rakus Baca & 2019 & Rakus Film \\
& & & Readpublik \\
4 & Bank Buku Butta Ilmu & $2015-2020$ & Komunitas Literasi Bantaeng \\
5 & Didaktif & 2020 & Perpustakaan Supiati \\
\hline
\end{tabular}

SumberInstagram @sulhanyusuf, @mauliahmulkin, \#paradigmainstitute 
Nilai-nilai Gender yang terkandung dalam Aktivitas Literasi di Kampung Buku dan Paradigma Institute

Berdasarkan kegiatan tersebut, peneliti mengidentifikasi nilai-nilai gender yang terinternalisasi, nilai-nilai tersebut adalah nilai keterbukaan, nilai kesetaraan, dan nilai kerja sama.

\section{Nilai Keterbukaan}

Terkait bagaiamana AR membuka rumahnya di Kampung Buku, pustakawan WS (21 thn) menyatakan

Awalnya penelitian, terus ikut kelas menulis tahun 2018, 2019 mulai gabung dan belajar, kerja di sana, urus Kampung Buku, Tanah Indie, Makassar Biennale. Sejak 2019 akhir saya bantu manajerial toko dan menjalankan program di Tanah Indie. Dan sejak 2019 itu intens hampir tiap hari ke sana.

Begitupun dengan RF (25 thn)

Kalau saya pribadi, awalnya Cuma belajar menulis dan meneliti di Tanah Indie. Kampung Buku dijadikan sebagai tempat berkumpul, ngobrol santai, dan bikin kegiatan. Seiring waktu, akhirnya saya diundang bergabung dalam grup wasap dan diminta untuk bantu-bantu sekaligus belajar bareng sama teman-teman

Baik RF maupun WS sejak 2018 menjadi pengunjung lalu menjadi pustakawan di sana dan datang setiap hari. Hal ini menunjukkan bahwa keluarga Kampung Buku secara sukarela menerima orang lain yang ingin datang untuk megakses perpustakaan atau untuk belajar di sana.

Proses ini juga sama dialami di Paradigma Institute. pustakawan di Paradigma menyatakan

Saya terlibat aktif di kegiatan-kegiatan Paradigma Institute belum terlalu lama. Kira-kira dimulai sekitar tahun 2014, yang berarti belum genap 10 tahun. Meski demikian, interaksi saya dengan Kak Sulhan jauh lebih awal ketika saya sering menjadikan TB Papirus sebagai "kos" kedua (BS 25 thn)

Juga dinyatakan peserta kelas literasi dan kelas parenting menyatakan

Saya kenal K Zulhan sejak 2005 dan 2009 samapai sekarang sering berinteraksi di paradigma, karena salah satu komunitas saya ada di sana dan hampir setiap pekan saya ke sana (MN 38 thn) 
Dari pernyataan keduanya, kita bisa mengetahui bahwa rumah keluarga Paradigma Institute telah lama bisa diakses untuk umum. BS bahkan menyatakan bahwa rumah itu telah dijadikan sebagai kos keduanya.

Untuk Paradigma Institute hal serupa ini sudah dilakukuan sejak 1998. Hal tersebut diterangkan istri pegiat Paradigma Institute

Lumayan lama itu karena setelah 98 misalnya teman-teman HMI ada acara di Makassar, pasti ngnapnya di rumah sampai berhari-hari. Merekabilang ini rumah Losmen Pabbentengang dan mungkin tidak mereka lupakan. (MM 45thn)

Jadi, memang semangat keterbukaan di komunitas ini sudah ada sejak lama, bahkan sejak anak-anak mereka kecil.

Dalam melihat ini, anak dari pegiat Paradigma Institute menyatakan

jadi $k$, saya ingat memang sejak kecil rumahku selalu ramai, selalu banyak orang, sejak umur 4 tahun kayanya, saya ingat umiku selalu masak banyak, orang selalu datang dan pergi. Sampai-sampai selalu datang pencuri ke rumahku, nda ada yang tau saking banyak nya orang lalulalang di rumah. (NAM/24 thn)

Dari pernyataan ini, sangat jelas bahwa anak sejak kecil secara alamiah menerima kondisi rumah mereka yang terbuka bagi banyak orang. Bahkan untuk anak dari pegiat Paradigma Institute JI (11 thn) merasa biasa-biasa saja saat ia harus berbagi kamar dengan pustakawan perempuan yang menyiapkan program sampai malam. Sebagaimana pernyataannya sebagai berikut

Saya sudah biasa berbagi, seperti sekamar dengan anak anak yang datang, dan tidak masalah (JI11 tahun)

Paradigma Institute dan Kampung Buku, keduanya sebagaimana terlihat pada table membuka kesempatan yang luas bagi banyak orang untuk belajar.

Nilai Kesetaraan

Nilai kesetaraan juga teridentifikasi dengan diberinya kesempatan bagi siapa saja untuk belajar dan terlibat di dalam komunitas melalui tahapan yang telah disepakati bersama.

Hal ini juga dinyatakan WS (24 thn) melalui wawancara bahwa mereka dalam berkegiatan di Kampung Buku diberi kebebasan berpendapat, diberi kesempatan belajar dan tidak digurui walau umur dan pengalaman mereka jauh berbeda

Dan bahkan K Piyo itu bisaki, misalnya ada satu pekerjaan yang dia tidak ada di situ, dia selalu kasi masukan. Tapi nda pernah kelihatan menggurui. 
Dia tahu bagaimana, K Piyo dan K Jim tahuki korideor kerja, tau bagaiaman memperlakukan orang lain terlihat tidak lebih rendah dari pada mereka.

\section{Nilai Kerja sama}

Bukan hanya itu, pustakawan dan peserta program lainnya diberikan pembagian kerja sesuai dengan kemampuan mereka. bukan berdasarkan jenis kelamin. Baik pekerjaan fisik seperti merenovasi tata letak perpustakaan, mengatur rak dan buku, mengecat dinding, perempuan dan laki-laki diberi porsi sesuai dengan kemampuan mereka.

Juga melalui program Memasak di Halaman, pustakawan dan pengunjung baik laki-laki dan perempuan bekerja menyiapkan kebutuhan domestic pustakawan.

Di Paradigma Institute, pegiat SY (55thn) dan istrinya MM (43 thn) terpaut umur yang jauh dari mayoritas peserta program dan pengunjung perpustakaan. Walau terpaut umur yang cukup jauh, namun suasana belajar yang diciptakan sangat setara tanpa memperhatikan senioritas. Dalam penentuan program kerja, SY dan MM selalu mengutamakan proses diskusi bersama pustakawan lainnya.

Dalam menjalankan aktivitas perpustakaan, pekerjaan antara pemilik perpustakaan dan pengunjung dibagi secara proporsional. Penyediaan logistic untuk kelas dan diskusi juga tidak ditentutekan berdasarkan jenis kelamin, namun berdasarkan kesanggupan pustakawan dan mengutamakan proses kolektivisme. Kedua komunitas ini memperlihatkan nilai-nilai kesetaraan dalam kegiatan mereka.

Sikap yang menjunjung asas keterbukaan dan kesetaraan yang ditunjukkan melalui aktivitas literasi di Paradigma Institute dan Kampung Buku yang telah peneliti bahas sebelumnya membuat dua komunitas ini bertahan lebih dari satu dekade sebagai ruang belajar alternative di Makassar.

Selain dua hal tersebut, ada etos kolaborasi yang selalu mereka jaga dalam setiap program ataupun kegiatan. Kolaborasi atau kerja sama yang mereka tunjukkan bukan hanya dalam internal komunitas mereka namun juga secara eksternal.

Secara internal, semua kegiatan yang dilakukan baik kegiatan mingguan, bulanan maupun tahunan, dilakukan secara bersama-sama. Pembagian kerja yang telah disepakati dilakukan secara sadar. Misalnya dalam kegiatan diskusi buku rutin di Kampung Buku dan Paradigma mereka sama-sama mempersiapkan, mengurus keperluan, menghubungi narasumber, mendokumentasikan dan mempublikasikan hingga acara selesai. 
Etos dan nilai kerja sama serta kesetaran yang terus dijaga komunitas ini, menurut $\mathrm{F}(39$ thn) dari Kampung Buku tidak lain karena sejak awal mereka membuka diri dan menerima semua yang datang untuk sama-sama belajar.

"kalau saya sih, keterbukaan. Soalnya kalo misalnya kita mau bertahan lama, tetap apa yang kita kerjakan bisa suistanble toh, menurutku keterbukaan itu penting, karena dia bagian dari keberlanjutan. Orang bisa percaya kita, mau kerja sama, mau kolaborasi, karena kita terbuka."

Relasi Gender dalam Keluarga Kampung Buku dan Paradigma Institute

Setelah mengidentifikasi nilai-nilai gender melalui aktivitas literasi di rumah keluarga pegiat literasi ini, Peneliti menegidentifikasi relasi gender melalui proses pengambilan keputusan dalam keluarga yang meliputi tiga hal yaitu pengambilan keputusan dalam pembagian kerja, pengambilan keputusan dalam pengasuhan anak dan pengambilan keputusan dalam pendidikan anak

Di kedua keluarga ini proses pengambilan keputusan dilakukan selalu bersama-sama. Mulai dari hal-hal kecil hingga hal-hal besar. SY (54thn) dari Paradigma Institute mengakui semua hal dalam keluarganya, diupayakan untuk selalu dibicarakan

Saya selalu menganggap istri itu pasangan saya. jadi namanya pasangan saling melengkapi dalam pengambilan keputusan tidak ada unsur yang dipaksakan. Biasa kadang-kadang diputuskan oleh dia, saya mengiyakan.

Hal ini dibenarkan oleh pustakawan, $\mathrm{MN}$ (38 thn) yang sering yang mengamati proses tersebut di Paradigma Institute

"Kalau saya mereka setara, dalam berkomunikasi dan pengambilan keputusan, karena mereka sama-sama punya pengetahuan"

Begitupun diakui oleh F(39thn), istri pegiat di Kampung Buku. Sebagai istri dia menganggap berdiskusi adalah metode termudah dalam menghasilkan keputusan di dalam keluarga mereka

"..kan kita semua ini di rumah, semua dibicarakan. Saya kan agak komunikatif, K Jimpe kan agak pendiam toh? Apapun saya tanya dulu, apapun saya obrolkan dulu. Walaupun akhirnya bilangji "kita ji, terserah kita". Tapi sebisa mungkin saya kasi tau dia, apapun itu semuanya saya obrolkan..."

Dalam pembagian kerja, peneliti menemukan ada pembiasaan kepada setiap anggota keluarga untuk mengerjakan pekerjaan berdasarkan kemampuan dan 
berdasarkan efektifitas. Bukan berdasarkan jenis kelamin atau berdasarkan status dalam keluarga.

Baik di Paradigma Institute maupun di Kampung Buku, siapapun bisa mengambilalih dapur dan mengerjakan pekerjaan rumah tangga lainnya. Bergantung pada pembagian kerja yang sudah disepakati.

Di Paradigma Institute, karena keempat anaknya sudah di usia dewasa dan beranjak remaja, pembagian kerja melibatkan semua orang di dalam rumah. Ibu hanya bertindak sebagai manajer yang mengatur pembagian kerja dan memastikan pekerjaan dilakukan.

Tabel 7. Keaktifan pekerjaan dalam rumah tangga keluarga Kampung Buku

\begin{tabular}{cllll}
\hline NO & JENIS PEKERJAAN & SUAMI & ISTRI & ANAK \\
\hline 1 & Memasak & $\mathrm{x}$ & $\mathrm{xxx}$ & $\mathrm{xx}$ \\
2 & Mencuci Piring & $\mathrm{xx}$ & $\mathrm{xx}$ & $\mathrm{xxx}$ \\
3 & Mencuci Baju & $\mathrm{xxx}$ & $\mathrm{xxx}$ & $\mathrm{xxx}$ \\
4 & Merapikan rumah & $\mathrm{xx}$ & $\mathrm{xx}$ & $\mathrm{xxx}$ \\
5 & Membersihkan halaman & $\mathrm{xxx}$ & $\mathrm{x}$ & $\mathrm{xx}$ \\
6 & Menyetrika & $\mathrm{xx}$ & $\mathrm{xx}$ & $\mathrm{xx}$ \\
7 & Belanja (harian/bulanan) & $\mathrm{x}$ & $\mathrm{xxx}$ & $\mathrm{x}$ \\
\hline
\end{tabular}

Sumber data primer 2020

Di Kampung Buku anaknya, masih berusia 11 tahun sehingga pemberian contoh menjadi sangat penting yang dilakukan oleh orang tuanya. Bobel hanya bertanggungjawab penuh terhadap kebersihan diri dan kamarnya. Itupun dibarengi dengan penghargaan berupa hadiah atau pujian saat dia melakukannya dengan baik.

Tabel 8. Keaktifan pekerjaan dalam rumah tangga keluarga Paradigma Institute

\begin{tabular}{cllll}
\hline NO & JENIS PEKERJAAN & SUAMI & ISTRI & ANAK \\
\hline 1 & Memasak & $\mathrm{xx}$ & $\mathrm{xxx}$ & $\mathrm{x}$ \\
2 & Mencuci Piring & $\mathrm{xx}$ & $\mathrm{xx}$ & $\mathrm{xxx}$ \\
3 & Mencuci Baju & $\mathrm{xxx}$ & $\mathrm{xx}$ & $\mathrm{x}$ \\
\hline
\end{tabular}




\begin{tabular}{cllll}
\hline NO & JENIS PEKERJAAN & SUAMI & ISTRI & ANAK \\
\hline 4 & Merapikan rumah & $\mathrm{xx}$ & $\mathrm{xxx}$ & $\mathrm{x}$ \\
5 & Membersihkan halaman & $\mathrm{xxx}$ & $\mathrm{x}$ & $\mathrm{xx}$ \\
6 & Menyetrika & $\mathrm{xxx}$ & $\mathrm{xx}$ & $\mathrm{x}$ \\
7 & Belanja (harian/bulanan) & $\mathrm{x}$ & $\mathrm{xxx}$ & $\mathrm{x}$ \\
\hline
\end{tabular}

Sumber data primer 2020

Ket :

$\mathrm{x}$ : tidak aktif

$\mathrm{xx}$ : aktif

$\mathrm{xxx}$ : aktif sekali

Diutarakan AR (44thn) tentang pekerjaan rumah yang harus turut dikerjakan anaknya

"iya, soalnya keterampilan hidup. Dan harus dimiliki, kami justru khawatir kalau hal-hal dasar itu tidak bisa dia kerjakan"

Dalam pembagian kerja, peneliti akan menampilkan bagaimana pekerjaan domestik kedua keluarga dalam bentuk table

Pada tabel 7 dan tabel 8 menunjukkan bahwa dalam rumah tangga Kampung Buku, kegiatan domestic bukan hanya dikerjakan oleh perempuan (istri) tetapi suami dan anak anak juga mengambil bagian meskipun porsinya bervariasi. Bahkan ditemukan bahwa kegiatan mencuci pakaian, menyetrika merupakan pekerjaan perempuan (istri) berdasarkan nilai budaya, justru dikerjakan oleh laki laki (suami).

Dalam hal pengasuhan anak walau suami dan bapak di dua keluarga ini mengakui, bahwa masing-masing istrinya mendominasi pengasuhan anak, namun mereka tidak serta merta berhenti berkontribusi. Dan yang paling utama, anakanak mereka diajak untuk sama memikirkan apa yang sebaiknya ia terima dalam proses ini.

Pustakawan dari Kampung Buku memperhatikan bagaimana keluarga ini menerapkan pola pengasuhan bagi anak-anaknya. Dia menyatakan bahwa suami istri saling mengisi dalam pengasuhan anak mereka

“. jadi, kan bobel homeschooling jadi kelihatannya mereka berdua ke Bobel itu seperti.., kalau misalnya K Piyo yang selalu kasi ingat Bobel " belajarmi bobel, mengajimi bobel, dia bagian mengingatkan.kalau misalnya Bobel jam 10 malam 
nda mau tidur, baru $k$ Jim tegur Bobel, kaya begitue. Jadi, seperti anak kecil yang lain, kalau tidak mau di kasi tau, dimaahiji, tapi nda dibentak-bentakki, caranya yang berbeda. Kalau misalnya Bobel lagi rapatki, dia mengganggu, rapatki, ributki, Bobel ditegurji juga. Bobel juga dkasi terlibat sama kami. tapi, kalau bikin salah dia dimarahi di depannya kami, misalnya kalau makan sembarang.." WS(21thn)

Menurut F (39thn), dia dan suaminya AR (44thn) saling bekerja sama mengingatkan untuk tumbuh kembang anak. Mulai dari kesehatannya, pola makan, pola tidur, kebiasaan. Mereka saling mengisi.

Di Paradigma Institute, istri menyatakan bahwa

Saya lebih dominan, saya konseptor dan eksekutor. 70\% .butuh usaha untuk mencocokkan pengetahuan orang tua. Dan KZulhan selalu membantu. kita tidak behenti belajar, sama-sama belajar. Untuk sampai pada titik keseimbangan, itu perjuangan (MM 45thn)

Artinya, selain memikirkan bagaimana pengasuhan keempat anaknya, istri dan suami sama-sama mencari pola yang cocok sesuai dengan karakteristik anak. dan, suami SY (54thn) tidak keberatan melakukan pola pengasuhan yang disarankan istrinya. Dia terbuka akan saran dan tidak merasa inferior dengan keputusan istrinya.

NAM (24thn) anak di keluarga Paradigma Institute, membenarkan bahwa

"Mereka selalu punya semangat untuk mempelajari hal-hal baru dan tidak pernahki merasa tua untuk belajar. Yang paling utama misalnya menghadapi anaknya. Abiku belajar."

Peserta kelas listerasi juga melihat bahwa dalam pengasuhan anak mereka sangat demokratis dan tidak membebani anak

“..Sebagai orangtua, saya melihat mereka berdua demokratis saja dalam membina anak-anaknya. Bahkan, sepengetahuan saya, dalam memberlakukan anak-anaknya, mereka berdua membuat anak-anaknya seolah-olah sebagai teman diskusi. Selain, Javid, ketiga anak perempuan Kak Sulhan sudah masuk usia kuliah. Dalam hal berorganisasi misalnya, Kak Sulhan membebaskan anakanaknya untuk melanglangbuana kemana saja." BS(24thn)

Untuk pendidikan anak, kedua keluarga juga sama-sama memperlihatkan tentang pentingnya terlibat dan melibatkan anak dalam menentukan pendidikan mereka. Di Paradigma Institute, pegiat literasi membangun analogi dalam melihat perkembangan pendidikan anaknya 
Ada ilustrasi yang saya bangun secara pribadi.misalnya anak itu, mulai dari Balita-SMA itu sentralisasi, ketika masuk perguruan tinggi, dia desentralisasi, saat sudah selesai kuliah artiny a sudah otonomi, pada saat sudah mau berkeluarga sudah referendum. Itu pikiran yang saya bangun. Sentralisasi yang pengambilan kebijakannya juga melalui proses diskusi. Sudah kuliah ada desentralisasi, kalau dia sudah selesai, sudah otonom (SY 54thn)

Dari pernyataan di atas SY (54thn) ingin mengatakan bahwa dia tidak sepenuhnya ingin mengatur anak tentang pilihan sekolah, tapi mengutamakan proses diskusi dan minat anak.

Anak keluarga ini NAM (24thn) menyatakan bahwa proses belajar mereka didukung kedua orang tua. Dan merasa beruntung karena ia bisa mengajak keduanya berdiskusi

Ummiku itu bacaannya parenting, psikologis. Abi itu lebih bnyak baca politik, sosial,kemsyarakatan, yang lebih makro. Sejak saya kerja ini, saya merasa Abiku sangat dukung, dan merasa kalau dia selalu ada untuk diajak diskusi. Sejak itu, saya merasa tambah dekat sama mereka, terutama Abiku.

Walau ia akui, untuk urusan teknis pendidikan sebelum kuliah, dia melihat ibunya lebih berperan besar, seperti mengajari dia adik-adik, menemani megerjakan PR, dan mengurusi tugas sekolah. Namun, saat kuliah, bapaknya lebih sering ia ajak berdiskusi.

Di Kampung Buku sendiri, suami istri AR(44thn) dan F(39thn) memilih homeschooling untuk anaknya JI (11thn) setelah mencoba beberapa sekolah formal saat usia TK dan SD tapi tidak berhasil, dengan tetap melibatkan anaknya dalam keputusan tersebut.

Meskipun sampai sekarang tentang pendidikan. Misalnya yag formal, belumpaki kepikiran. Kemarin sempat dia bilang SMP, trus mundur lagi SMA

JI (11 thn) juga mengakui kalau dia belum mau sekolah formal, karena cerita tentang tidak enaknya sekolah ia dapatkan dari temannya

Iya, tapi kadang saya mauji juga sekolah. Tapi, kalau saya tanya temanku, bagaimana sekolah? Banyak yang bilang nda enak

Karena JI belajar dari rumah, maka tanggung jawab untuk pendidikan anak dibagi pada ayah dan ibu sesuai kemampuan. Suami AR (44thn) biasanya mengajak belajar tentang ilmu sosial, dan seni. Sementara istri bertugas mengajar bahasa dan matematika, dan mengatur jadwal belajar anak. 
Dari pemaparan di atas, ditemukan fakta menarik bagaimana dua keluarga ini membangun relasi berdasarkan nilai-nilai keterbukaan, kesetaraan dan kerja sama. Dalam keluarga, khususnya suami istri menciptakan relasi yang cair baik saat berkomunikasi maupun saat bekerja dengan asas kebersamaan atau kolektivisme.

Teori ekologi keluarga Bronfenbrenner menyatakan bahwa perkembangan manusiadipengaruhiolehkontekslingkungan. Hubungantimbalbalikantaraindividu dengan lingkungan akan membentuk tingkah laku individu. Bronfenbenner yang melihat lima sistem lingkungan berlapis yang saling berkaitan, yaitu mikrosistem, mesosistem, ekosistem, makrosistem, dan kronosistem. (Qurota,2019). Aktivitas literasi baik yang dilakukan di Paradigma Institute maupun di Kampung Buku telah berjalan lebih dari satu dekade dan dilakukan secara rutin, memperlihatkan bagaimana kedua keluarga sebagai lingkungan mikrosistem individu membentuk habitus bagi anak, istri dan suami.

Habitus menurut Arif Gumira (Arif, 2019) adalah pandangan hidup, nilainilai yang telah dipercayai dan dijalankan secara sadar. Proses habitus dalam keluarga terjadi melalui internalisasi nilai-nilai melalui tiga tahapan utama, tahap transformasi, tahap transaksi dan tahap transnternalisasi. (Siti,2013, h.14-15)

Berdasarkan hasil penelitian, kedua keluarga telah melewati tiga tahapan internalisasi. Tahapan transformasi nilai dilakukan suami kepada istri, begitupun sebaliknya sebelum membentuk keluarga. Masing-masing, baik istri maupun suami bersepakat terhadap nilai-nilai yang ingin mereka tanamkan dalam keluarga yang akan mereka bangun. Tahapan transformasi berikutnya adalah tahapan transformasi nilai kepada anak sejak dini yang dilakukan oleh suami dan istri kepada anak mereka melalui aktivitas literasi yang diinisiasi di rumah.

Aktivitas literasi yang dilakukan dua keluarga ini menunjukkan nilai-nilai keterbukaan, kesetaraan dan kerja sama. Membuka rumah pribadi sebagai ruang publik adalah salah satu indikator bahwa kedua keluarga ini telah berkomitmen untuk menjalani proses belajar yang terbuka dan mandiri. Ruang publik dalam pandangan Habermas memastikan bahwa setiap warga negara memilik akses untuk menjadi pengusung opini publik. Opini publik ini berperan untuk mempengaruhi, termasuk secara informal, perilaku-perilaku yang ada dalam 'ruang' negara dan pasar. Gagasan tentang ruang publik diartikan sebagai area terbuka dimana semua individu dan kelompok dalam sebuah bangsa atau negara memiliki hak yang setara 
untuk menyampaikan gagasan dan pendapatnya tanpa takut akan adanya intervensi baik oleh masyarakat maupun negara. (Noorrachman, 2018)

Sejalan dengan teori Habermas tersebut, menginisiasi ruang public berarti mencoba mewujudkan nilai-nilai keterbukaan, kesetaraan dan kerja sama di dalamnya. Nilai-nilai tersebut adalah yang juga termanifes dalam upaya pengarusutamaan gender dalam arah pembangunan masyarakat kita. Anak-anak di dua keluarga ini secara tidak langsung telah mengenal konsep keterbukaan, kesetaraan dan kerjasama sejak dini. Menurut Bronfenbrenner dalam perkembangan anak, orang tua memegang peranan penting dalam membentuk lingkungan tumbuh anak-anak mereka kelak (Anina,2019, h.14). Pelaksanaan aktivitas literasi di rumah yang melibatkan masyarakat umum secara terbuka dengan sengaja menunjukkan bahwa nilai-nilai tersebut ingin ditanamkan kepada anak-anak dalam keluarga mereka.

Tahapan internalisasi selanjutnya yaitu tahapan transaksi nilai dinilai berhasil ketika ada reaksi atas nilai-nilai yang diperkenalkan pada individu, reaksinya bisa menolak atau menerima. tahapan ini dilalui kedua keluarga dengan melibatkan anak dalam aktivitas yang dilakukan. (Titik,dkk, 2014,h.167) Pelibatan secara sederhana, misalnya dengan menjaga perpustakaan. Anak di Kampung Buku yang berusia 11 tahun, misalnya diberi tanggung jawab jadi pencatat tamu yang hadir, menjadi tim dokumentasi, atau ikut dalam program.

Anak di Paradigma Institute bahkan telah masuk dalam tahapan akhir proses internalisasi, yaitu transinternalisasi nilai karena anak telah menerima nilai dan melakukan hal yang serupa dalam keseharian mereka yaitu ikut sebagai pimpinan project dalam sebuah program dan ikut berkontribusi secara ideasional dalam pengembangan komunitas. Hal ini sejalan dengan teori ekologi yang memandang perkembangan manusia sebagai hasil interaksi atau transaksi antara kekuatan internal dan kekuatan eksternal. Interaksi merupakan dasar bagi perkembangan manusia. Interaksi diartikan sebagai aktivitas saling mempengaruhi antara kekuatan internal (organisme dengan berbagai atributnya) dan kekuatan eksternal (lingkungan: fisik, psikologis, maupun sosial). (Permanian, 2013.h.4)

Berdasarkan hasil penelitian, aktivitas literasi dalam hal ini adalah kekuatan eksternal, yang dilakukan dua keluarga ini telah menginternalisasi nilai-nilai gender dalam keseharian keluarga. Hal tersebut mempengaruhi perkembangan individu dalam penerimaan nilai hidup (kekuatan internal) yaitu nilai keterbukaan, kesetaraan dan kerja sama baik untuk suami, istri maupun anak. 
Nilai-nilai gender yang terinternalisasi melalui aktivitas literasi dalam keluarga pegiat literasi di Kampung Buku dan Paradigma Institute, memberikan dampak yang cukup besar dalam relasi gender dalam keluarga antara suami dan istri, kemudian antara orang tua dan anak. Hal tersebut bisa dilihat melalui satu variable yaitu pengambilan keputusan. Pengambilan keputusan merupakan perwujudan proses yang terjadi dalam keluarga dan merupakan hasil interaksi antara peran anggota keluarga untuk saling memengaruhi (Scanzoni dan Scanzoni, 1990). Dengan mengetahui pola pengambilan keputusan rumah tangga, dapat diketahui pula ada tidaknya dominasi di dalam suatu rumah tangga.

Menurut pandangan feminism sosialis, jika dalam keluarga mengantut asas kolektivisme dalam menjalankannya, maka penindasan terhadap perempuan tidak akan terjadi. Adanya relasi gender yang setara memungkinkan hubungan keluarga, baik itu suami istri, orang tua dan anak sebagai hubungan yang adil dan tidak merugikan satu diantaranya baik itu laki-laki maupun perempuan.

"Gender equality, equality between men and women...does not mean that women and men have to become the same, but that their rights, responsibilities and opportunities will not depend on whether they were born male or female. Gender equity means fairness of treatment for men and women according to their respective needs. This may include equal treatment or treatment that is different but which is considered equivalent in terms of rights, benefits, obligations, and opportunities." -United Nations Educational, Scientific and Cultural Organization.(Pipeline, 2018)

Dalam dua keluarga tersebut yang tergambar melalui Bagan 01. Bagan Proses Pengambilan Keputusan dalam Keluarga Paradigma institute dan Kampung Buku, pengambilan keputusan selalu melalui proses bermusyawarah. Baik oleh suami kepada istri, ayah kepada anak, ibu kepada anaknya ataupun sebaliknya. Baik dalam memutuskan perkara yang besar maupun masalah kecil. Masalah kecil, misalnya dalam menentukan warna cat rumah, meemilih perabot, dekorasi, menentukan makananan yang ingin dimakan, atau memikirkan cara mengisi akhir pekan bersama. Semua selalu dibicarakan dan melibatkan seluruh anggota keluarga.

Hal tersebut sejalan dengan cita-cita feminis sosialis bahwa sebaiknya relasi suami dan istri dalam keluarga adalah relasi yang tidak bersifat superior dan inferior. Perempuan cenderung mengalah pada suami demi keharmonisan keluarga, demi status, demi persespsi sosial masayarakat. (Angger,2015) Dan dua keluarga ini 
berupaya untuk membangun relasi yang tidak saling mengeasikan satu dengan yang lainnya.

Penelitian ini berfokus pada pengambilan keputusan dalam pendidikan anak, pengasuhan anak dan pembagian kerja dalam rumah tangga. Ketiga hal tersebut dalam masyarakat patriarki biasanya dibebankan pada ibu semata. Manneke Budiman menyebutkan bahwa perempuan walaupun berkarya di ranah publik terus saja dibebani dengan tanggung jawab domestik seperti mengasuh anak, mengurus rumah, memasak, menyiapkan kebutuhan keluarga, membayar tagihantagihan dan pekerjaan domestik lainnya. Serta harus mempertimbangkan berbagai persoalan keuangan, pendidikan, serta sosial maupun keharmonisan keluarga. (Manneke, 2013)

Dalam pendidikan dan pengasuhan anak, diakui dua keluarga tersebut bahwa istri lebih mendominasi dalam urusan ide dan gagasan. Namun, suami dilibatkan penuh dalam prosesnya. Suami membantu proses pengasuhan dan pendidikan anak. Di Kampung Buku yang memilih homeschooling untuk anaknya melibatkan ayah dan ibunya dalam porsi yang sama sesuai kemampuan mereka untuk menjadi guru bagi anaknya. Begitupun di Paradigma Institute, suami mengambil porsi sesuai dengan kapabilitasnya saat terlibat didalam pendidikan dan terlibat penuh dalam proses pengasuhan anak sejak mereka kecil.

Relasi yang terbuka dan setara paling jelas terlihat dalam pembagian kerja rumah tangga. Berdasarkan Table 04 dan Table 05 terlihat keaktifan suami sitri dalam melakukan aktivitas rumah tangga hampir sama. Hal ini secara langsung memang diakui oleh suami di dua keluarga tersebut, bahwa pembagian kerja tidak berdasarkan pada status, jenis kelamin dan umur mereka, namun berdasarkan pada kemampuan kerja.

\section{SIMPULAN DAN SARAN}

Pembangunan berperspektif gender di Indonesia hingga hari ini belum mencakup pada pembangunan yang mengintegariskan nilai-nilai gender dalam skala mikro, yaitu keluarga. Sementara untuk mengharapkan terwujudnya masyarakat berperspektif gender, keluarga harus terlibat dalam proses tersebut. Salah satu pelibatan adalah melihat kemungkinan terinternalisasinya nilai-nilai gender dalam aktivitas yang dilakukan keluarga.

Penelitian yang dilakukan pada dua keluarga aktivis literasi di Makassar terkait aktivitas literasi yag diiinisiasi di rumah mereka, menunjukkan bahwa ada nilai- 
nilai gender dalam aktivitas pendirian perpustakaan dan inisiasi ruang belajar. Nilai-nilai gender yang dimaksud adalah nilai keterbukaan, keseteraan, dan kerja sama. Dan nilai-nilai yang telah terinternalisasi tersebut berpengaruh dalam proses pengambilan keputusan dalam keluarga.

Melalui penelitian ini, peneliti menyarankan agar sebaiknya kegiatan literasi berbasis komunitas bisa digunakan sebagai metode penanaman nilai gender sejak dini dalam keluarga. Dan,untuk lebih oprimalnya peran dari keluarga pegiat literasi, maka diperlukan dukungan pemerintah untuk memberikan dukungan berupa penambahan fasilitas agar aktivitas yang dilakukan bisa menjangkau lebih banyak orang.

\section{DAFTAR PUSTAKA}

Adriana, I. (2009). Kurikulum Berbasis Gender (Membangun Pendidikan yang Berkesetaraan). TADRIS: Jurnal Pendidikan Islam, 4(1).

Andayani, B. (2015). Tinjauan pendekatan ekologi tentang perilaku pengasuhan orangtua. Buletin Psikologi, 12(1).

Fakih, M. (2008). Analisis gender dan transformasi sosial. Insist Press.

Gender Equity Vs. Gender Equality: What's the Distinction?. https://www. pipelineequity.com/voices-for-equity/gender-equity-vs-gender-equality/ diakses hari Sabtu, 27 Juni 2020

Hakim, L. (2012). Internalisasi Nilai-Nilai Agama Islam dalam Pembentukan Sikap dan Perilaku Siswa Sekolah Dasar Islam Terpadu Al-Muttaqin Kota Tasikmalaya. Jurnal Pendidikan Agama Islam-Ta’lim, 10(1), 67-77.

Håklev, S. (2010). Factors that contributed to the community library movement in Indonesia.

Harcourt.Wendy And Arturo Escobar, 2016 Building Community Economies:Woman in Politic Place, The Palgrave Handbook of Gender and Development, England :The Palgrave Handbook

Hasler, A., \& Lusardi, A. (2017). The gender gap in financial literacy: A global perspective. Global Financial Literacy Excellence Center, The George Washington University School of Business.

Herdiansyah, H. (2015). Metode penelitian kualitatif untuk ilmu psikologi. Jakarta: Salemba Humanika. 
Herdiansyah, H. (2016). Gender dalam Perspektif Psikologi. Jakarta: Salemba Mahardika

Herien Puspitawati. (2015) Tekhnik Analisis Gender dalam Penelitian Bidang Ilmu Keluarga untuk Masukan bagi Kebijakan Daerah Responsif Gender Departemen Ilmu Keluarga dan Konsumen Fakultas Ekologi Manusia, Institut Pertanian Bogor

Komisi Nasional Anti Kekerasan Terhadap Perempuan. (2020). Catatan Akhir Tahun. Jakarta

Maulana, A. M. R. (2013). Feminisme sebagai Diskursus Pandangan Hidup. Kalimah: Jurnal Studi Agama dan Pemikiran Islam, 11(2), 271-286.

Moreno-Mínguez, A., Ortega-Gaspar, M., \& Gamero-Burón, C. (2019). A sociostructural perspective on family model preferences, gender roles and workfamily attitudes in Spain. Social Sciences, 8(1), 4.

Mosse, J. C. (2002). Gender dan pembangunan. Yogyakarta: Pustaka Pelajar

Nasional, T. P. G. L. (2017). Panduan Gerakan Literasi Nasional. Jakarta: Kementerian Pendidikan dan Kebudayaan.

Perry-Jenkins, M., \& Wadsworth, S. M. (2017). Work and family research and theory: Review and analysis from an ecological perspective. Journal of Family Theory \& Review, 9(2), 219-237.

Rahayu, Angger Wiji. (2015). Perempuan Dan Belenggu Peran Kultural. Diakses 14 Agustus 2020 https://www.jurnalperempuan.org/wacana-feminis/ perempuan-dan-belenggu-peran-kultural

Rahman, H. (2020). Internalisasi Nilai-Nilai Gender Melalui Aktivitas Literasi Dalam Keluarga Pegiat Literasi Makassar (Doctoral dissertation, Universitas Hasanuddin).

Rumpf, H. (1990). The characteristics of systems and their changes of state disperse. Part. Technol., Chapman and Hall, 8-54.

Rustina, R. (2017). Implementasi Kesetaraan Dan Keadilan Gender Dalam Keluarga. Musawa: Journal for Gender Studies, 9(2), 283-308.

Somad, P. (2013). Teori Ekologi sebagai Dasar Pengembangan Keterampilan Komunikasi Siswa Tunarungu Usia Pra-Sekolah. Jassi Anakku, 12(1), 97-111.

Suseno, F. M. (2015). Agama, Keterbukaan dan Demokrasi: Harapan dan Tantangan. Jakarta: Pusat Studi Agama. 
Widyaningsih, T. S., Zamroni, Z., \& Zuchdi, D. (2014). Internalisasi dan aktualisasi nilai-nilai karakter pada siswa SMP dalam perspektif fenomenologis. Jurnal Pembangunan Pendidikan: Fondasi dan Aplikasi, 2(2). 